Reprod. Nutr. Dévelop., 1980, 20 (6), 1859-1868.

\title{
Cryopreservation of rainbow trout sperm by deep-freezing
}

\author{
par M. LEGENDRE, R. BILLARD
}

Laboratoire de Physiologie des Poissons, I. N. R. A., 78350 jouy-en-Josas, France.

\begin{abstract}
Summary. Cryopreservation trials on rainbow trout (Salmo gairdneri) sperm were carried out using two basic extenders : Mounib's medium (M) and Ménézo's medium (Me) to which were added bovine serum albumin (BSA) and tellurite egg yolk (Institut Pasteur). After 10 p. 100 of DMSO was added to these different deep-freeze diluents (DD), they were mixed with the sperm and then deep-frozen into $100 \mu \mathrm{l}$ pellets on dry ice. The pellets were stored in liquid nitrogen for periods lasting from 3 days to 6 months. The intensity of sperm motility and fertilizing ability were measured before and after cryopreservation. After the sperm was diluted in Ménézo's medium, slight spermatozoon motility was noticed, which probably caused their early exhaustion and would explain the lower fertilizing ability observed after thawing. Mounib's medium gave better results, especially after 10 p. 100 of egg yolk was added. The optimal deep-freeze conditions were: $1 / 3$ dilution, no equilibration after dilution but immediate deep-freezing at a rate of 10 to $40 \mathrm{c} / \mathrm{min}$. Thawing had to be carried out rapidly in $10 \mathrm{sec}$. However, the spermatozoa were altered during the freezing-thawing process, and during insemination more frozen spermatozoa had to be used to equal the fertilization rate obtained with non-frozen sperm. However, the fertile spermatozoa gave normal embryogenesis and no abnormal development was seen up to the vesicle resorption stage. At the end of spermiation, sperm fitness for deep-freezing decreased, perhaps due to sperm senescence. Pooling the sperm of several males partially compensated for the loss of fertilizing ability seen at the end of the reproductive period.
\end{abstract}

\section{Introduction.}

Fish reproduction in temperate regions has a marked seasonal character, and different techniques may help to improve fish farm management by spreading juvenile production over the year. Several means may be used: (i) shifting spawning by changing the photoperiod or by hormone treatment, (ii) storage et gametes or embryos. Gamete storage also has precise applications ; it facilitates artificial insemination and permits crossing or hybridization of geographically distant fish or those whose reproductive period is different. In this paper, we report the cryopreservation of rainbow trout sperm.

In spite of numerous studies, the literature on salmonids is confusing. Hoyle and Idler (1968), then Truscott and Idler (1969) obtained partial success after deep-freezing Atlantic salmon sperm (12 and 19 p. 100 fertilization, respectively) ; Graybill and Horton (1969) also had limited success with the rainbow trout (18 p. 100). Ott and Horton $(1971 a, b)$ reported better results in the chinook salmon, coho salmon 
and rainbow trout (59 p. 100). However, a large amount of sperm was necessary for artificial insemination and the storage method, repeated in several laboratories, has not had great success. Recently, Stein and Bayrle (1978) deep-froze rainbow and brown trout sperm with 70 to 80 p. 100 fertilization, while Stoss ef al. (1978) obtained very variable results (2 to 80 p. 100). When using Stein's technique, Stoss ef al. (1978) had only 31 p. 100 fertilization. Finally, Mounib (1978) reported 80 p. 100 fertilization after deep-freezing salmon sperm and Erdahl and Graham (1978) obtained 90 p. 100 fertilization in the rainbow trout ; however, it is to be regretted that the type of deep-freeze diluent was not mentioned in the latter publication.

On the whole, the non-repeatable results obtained on different fish of the same species, the mediocre rate of success and the vagueness of some experimental conditions (amount of sperm used for artificial insemination, type of diluents used for freezing and thawing) show that no satisfactory technique has been developed for deepfreezing salmonid sperm.

The aim of the present work, carried out on the rainbow trout, is to define a repeatable, easy technique of deep-freezing. We studied the nature of the deepfreezing diluent, the sperm/diluent ratio and the crucial sperm dilution for insemination. « Intersperm » variability of deep-freezing fitness has also been discussed. The criteria used for evaluating sperm quality after thawing were motility, fertilizing ability and survival during embryonic development and vitelline resorption.

\section{Materials and methods.}

The experiments were carried out belween December 1978 and February 1979. The 2- to 3-year old males began spermiation at the beginning of November, and were fasted for $48 \mathrm{~h}$ before each sampling. They were anesthetized with $0.3 \mathrm{ml} / \mathrm{l}$ of phenoxyethanol, the genital papilla was dried and the sperm was squeezed by abdominal pressure into hemolysis tubes in melting ice, then stored on a refrigerated surface at $4^{\circ} \mathrm{C}$. We used only samples uncontaminated by urine or feces and having considerable motility after dilution in the insemination diluent (ID) (Billard, 1977). The sperm samples were studied either individually for intermale freezing fitness or after pooling to test the nature of the deep-freeze diluent. The latter technique made available a larger amount of material and limited the effect of defective sperm.

Salmonid spermatozoa are not spontaneously motile in the vas deferens or after collection. Their motility is initiated only after dilution in water or physiological saline, such as the diluent for insemination (ID), and lasts only a very short time : 30 to $60 \mathrm{sec}$. Thus, motility must not be initiated following dilution in the deep-freeze diluent (DD), and can be inhibited by the addition of potassium (Billard and Jalabert, 1974), sucrose (Billard, 1980) or both (Mounib, 1978). Mounib's diluent (sucrose $125 \mathrm{mM}$ ), reduced gluthation $6.5 \mathrm{mM}$, potassium bicarbonate $100 \mathrm{mM}, \mathrm{pH} 7.57$, Mounib, 1978) and Ménézo's INRA $B_{2}$ diluent (Ménézo, 1976) served as a basis for the development of an appropriate freezing medium, and were tested alone or in association at a ratio of $1 \mathrm{v} / 1 \mathrm{v}$. The Ménézo medium was partially successful in the cryopreservation of rainbow trout sperm (Billard, 1978). It includes various amino acids (total of $1.3 \mathrm{mg} / \mathrm{ml}$ ) BSA $(10 \mathrm{mg} / \mathrm{ml}$ ) in a bicarbonate buffer $0.03 \mathrm{M}, \mathrm{pH} 7.6$, o.p. $290 \mathrm{mil}$ - 
liosmoles. To improve the results, organic components were added to Mounib's diluent which is essentially mineral. We added $10 \mathrm{mg} / \mathrm{ml}$ of bovine serum albumin (BSA, Sigma A 43-78) as well as egg yolk at a concentration of 10 p. 100 of the final volume of diluent, which included a 10 p. 100 concentration of DMSO cryoprotector (vol/final vol.). In some cases, the yolk was added to those diluents (yolk with tellurite for Berde and Parker's medium ; Institut Pasteur). Semen and DD were mixed at $4{ }^{\circ} \mathrm{C}$ at a ration of $1 / 1,1 / 3$ or $1 / 9$ (vol sperm/vol diluent) with or without $1 \mathrm{~min}$ of equilibration ; the pellets were prepared by placing of the mixture on dry-ice, according to the technique of Nagase (1964), and then stored in liquid nitrogen for 3 days to 6 months. The fertilization ability of frozen sperm over a 6-month period was tested in August and the fresh gametes obtained at that time came from breeding fish which had been under decreasing photoperiod (16L-8D $\rightarrow 8 \mathrm{~L}-16 \mathrm{D})$ for 4 months to advance the period of reproduction.

The motility of the spermatozoa was observed under a microscope $(\times 100)$ before and after freezing ; the sperm was diluted 10 times in ID. An arbitrary scale of motility ( 0 to 5 , with intermediary values allowing more precision when intensity was low) was used (Sanchez-Rodriguez and Billard, 1977). For the fertilization tests carried out at $10^{\circ} \mathrm{C}$, batches of about 200 eggs, taken from a pool of several females, were mixed with 10 or $100 \mu$ l of fresh sperm (1/100 or $1 / 1000$ dilution rate) in $10 \mathrm{ml}$ of ID. Insemination with fresh or frozen semen was carried out with a constant number of spermatozoa. The pellets were thawed directly into the egg-diluent mixture. Thawing was accelerated by rapid shaking.

The percentage of embryonated eggs was determined after 30 days of incubation at $10^{\circ} \mathrm{C}$ and the percentage of hatching and mortality during the period of resorption were also determined.

Statistical analysis. - Percentage of fertilization were compared after angular transformation using different statistical tests adapted to the various experimental situation : $\chi^{2}$ tests, t-test and two-factor analysis of variance. To test the significance of the observed trends, the non-parametric sign test was used (comparison of dilution rates : fig. 1).

\section{Results.}

Comparison of tested diluents. - The results based on observed motility are given in tabl 1. Before freezing and without ID, only the Ménézo $B_{2}$ diluent initiated slight spermatozoa motility. With ID, the motility was the same as that of fresh sperm. After deep-freezing and without ID, motility was practically zero; the addition of ID induced low motility which remained weak with both diluents. The number of motile spermatozoa was considerably lower as compared to fresh sperm, but their movement was rapid and rectilinear. The observed motility with the other diluents tested (Mounib + BSA, Mounib + Ménézo, with or without yolk) was identical to that when Mounib's diluent was used. However, the addition of yolk slightly improved motility after thawing.

After insemination at a $1 / 100$ dilution, the fertilizing ability of sperm frozen without equilibration in Ménézo's $B_{2}$ medium gave much lower results than with Mounib's 
Intensity of motility and fertilizing ability of rainbow trout sperm before and after deep-freezing following dilution in Mounib and Ménézo $B_{2}$ diluents for cryopreservation (DD). Motility was checked with or without dilution in insemination diluent (ID). 1 vol. sperm/10 vol. ID). Fertilizing ability was tested after insemination in ID (dilution $1 / 100$ ).

\begin{tabular}{|c|c|c|c|c|c|c|c|}
\hline \multirow[b]{3}{*}{ DD } & \multirow[b]{3}{*}{$\begin{array}{l}\text { dilution } \\
\text { vol. sperm/ } \\
\text { vol. DD }\end{array}$} & \multicolumn{4}{|c|}{ Motility } & \multicolumn{2}{|c|}{ p. 100 Fertilization } \\
\hline & & \multicolumn{2}{|c|}{ before freezing } & \multicolumn{2}{|c|}{ after thawing } & \multirow[b]{2}{*}{$\begin{array}{l}\text { frozen } \\
\text { sperm }\end{array}$} & \multirow[b]{2}{*}{$\begin{array}{c}\text { fresh } \\
\text { sperm } \\
\text { (control) }\end{array}$} \\
\hline & & $\underset{\text { sperm }}{\text { s.- }}$ & $\begin{array}{c}\text { sperm t- } \\
D D+\text { ID }\end{array}$ & $\begin{array}{l}\text { spontaneous } \\
\text { motility }\end{array}$ & $\begin{array}{l}\text { sperm } \dashv- \\
\text { ID }\end{array}$ & & \\
\hline \multirow{3}{*}{ Mounib } & $1 / 1$ & $0 \nmid$ & 4 & $0+$ & $1-$ & 2.4 & \\
\hline & $1 / 3$ & $0+-$ & 4 & $0 \div$ & $1 \div$ & 71.4 & \\
\hline & $1 / 9$ & $0 \nmid$ & 3 & $0+$ & $2-$ & 31.4 & 93.7 \\
\hline \multirow{3}{*}{ Ménézo $B_{2}$} & $1 / 1$ & $1-$ & 4 & 0 & $1-$ & 0 & \\
\hline & $1 / 3$ & 1 & 4 & $0 \dashv$ & $1-$ & 31.6 & \\
\hline & $1 / 9$ & 2 & 4 & $0+$ & $1-$ & 12.7 & \\
\hline
\end{tabular}

medium $(P<0.001)$ (table 1). When those media were used alone, together (Mounib + Ménézo $B_{2}$ ) or after BSA was added, there was no significant difference ( $t$-test) between their fertilization rates (fig. 1). On the contrary, when 10 p. 100 of yolk was added, fertilizing ability after thawing was distinctly improved and the results were less variable. That effect was particularly clear with the $1 / 1$ dilution $(P<0.01)$ and occurred again with the $1 / 3$ dilution $(P<0.05$ ), except for Mounib's medium + BSA (at the significance limit). At a dilution of $1 / 9$, the fertilizing ability was not improved by adding yolk to the DD. In general, the $1 / 3$ dilution improved the fertilization percentages as compared to other dilutions $(P<0.05)$, except with the combinations of Mounib + BSA + yolk and Mounib + Ménézo $B_{2}+$ yolk, which gave the same results as the $1 / 1$ and $1 / 3$ dilutions.

When we let the sperm-DD mixture equilibrate for $1 \mathrm{~min}$ before putting it on dry-ice, its fertilizing ability was the same as that of fresh sperm, but decreased significantly after deep-freezing $(P<0.05)$ (insemination at a $10^{-2}$ dilution, fig. 2 ). On the contrary if no equilibration time was allowed the fertilizing capacity, at $10^{-2}$ dilution, was usually the same before and after freezing (see fig. 3).

Effect of dilution rate on inseminated sperm. - The fertilizing ability of frozen or non-frozen sperm after dilution in 3 DD, Mounib, Mounib + BSA, Mounib + yolk was tested. Insemination was carried out at $1 / 100$ and $1 / 1000$ in the ID. The $1 / 1000$ dilution of frozen sperm always gave significantly lower fertilization rates $(P<0.001)$ than the 1/100 dilution, which showed values similar to those obtained with the nonfrozen control sperm diluted at 1/1000 (fig. 3). Thus, more frozen spermatozoa were needed to equal the fertilization percentages obtained with non-frozen spermatozoa. 


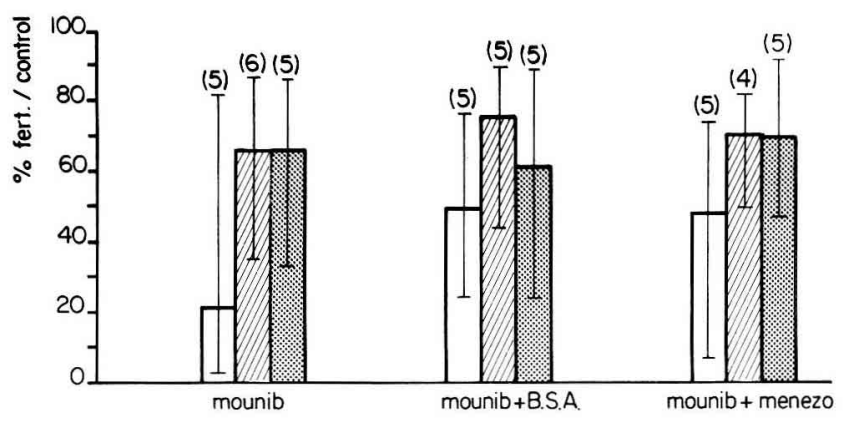

Diluents without yolk
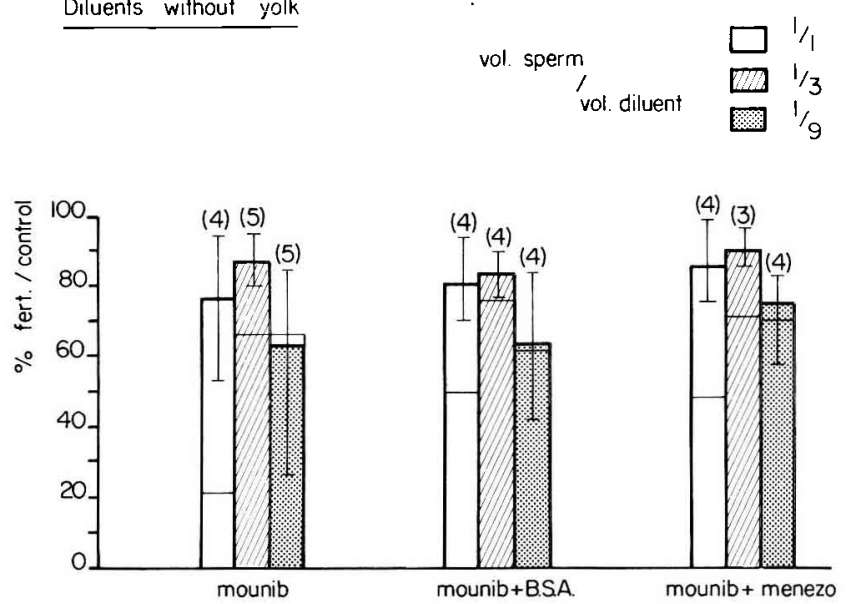

Diluents with yolk

FIG. 1. - Comparison of the fertilization percentages obtained after deep-freezing in Mounib, Mounib + BSA, and Mounib + Ménézo with or without egg yolk and $3 \mathrm{sperm}$ dilution rates. The deviations are the lower (LL) and upper (UL) limits observed ; Fertilization percentages obtained for the controls : $\bar{x}=88.8$, LL 75 p. 100 , UL 98 p. 100, non parametric test (see text) ; ( ) : number of observations.

"Intersperm》 variation in sperm fitness for deep-freezing and cryopreservation. This experiment was carried out at the end of spermiation in mid-February. The sperm of 9 males, studied individually or pooled (equal male contribution), was frozen and the pellets stored either for several hours in dry-ice or for 6 months in liquid nitrogen before being used for insemination. The results obtained showed that there were few individual differences among the 9 males $(P<0.1)$, whatever the mode and length of storage. Before deep-freezing, the fertilizing ability of the pooled sperm was equal to that of the mean of the individual males, but after freezing the fertilizing ability was better than that of the best males, whether the sperm was stored for several hours or deep-frozen for 6 months $(P<0.05$ in both cases). It thus seems that the fertilizing ability did not decrease after 6-month storage of either the pooled sperm or that of the whole of the 9 males. 


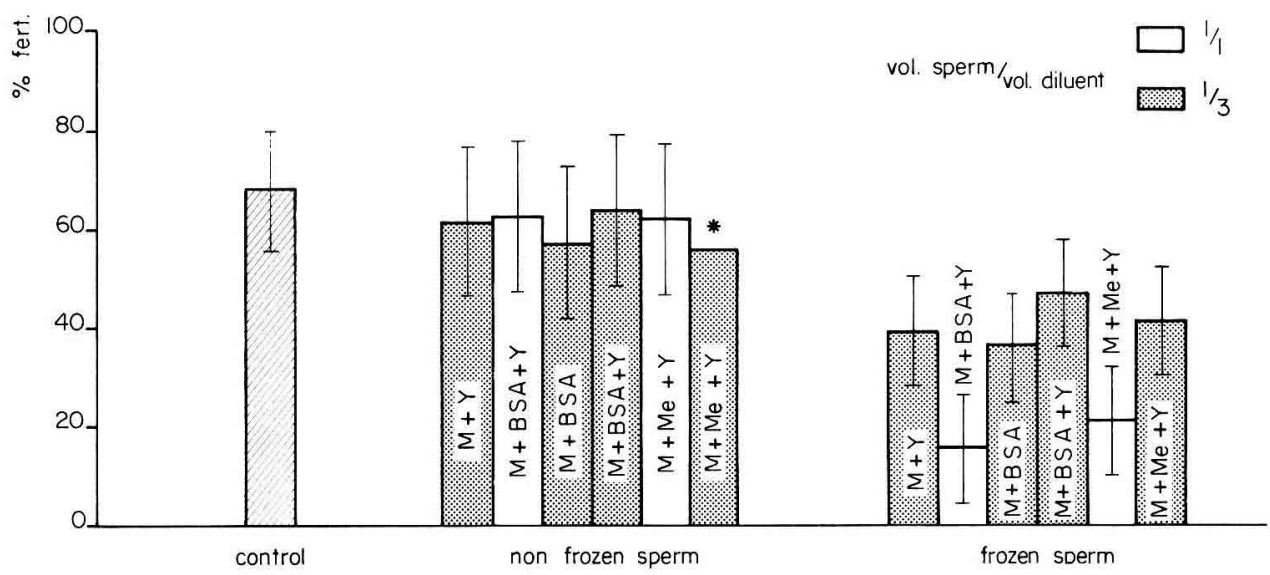

FIG. 2. - Effect of deep-freeze diluents and of the dilution rate on sperm fertilizing ability before and after deep-freezing. Sperm and diluent were mixed and left for equilibration during one min. before insemination (non frozen sperm) or before freezing. ( $M$ : Mounib; Me : Ménézo ; $Y$ : yolk). The deviations are the mean confidence interval \pm 5 p. 100 for 4 repeats ; $* 2$ repeats only. Controls : freshly collected sperm before adding diluent.

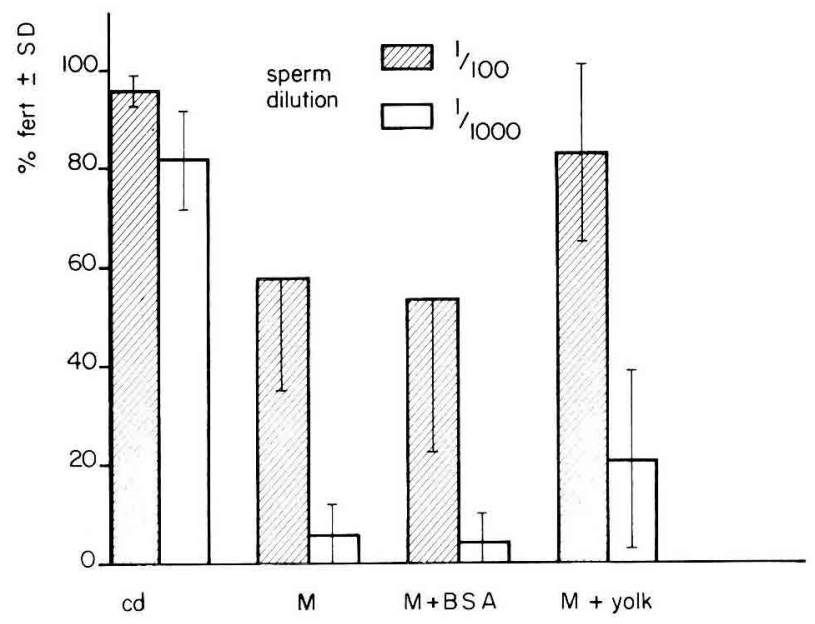

FIG. 3. - Effect of sperm dilution af insemination on fertilizing ability of non-frozen (control) sperm and deepfrozen sperm in Mounib (M), Mounib + BSA and Mounib + yolk diluents (no equilibration was allowed).

Effect of deep-freezing sperm on embryonic survival. - Examination during embryogenesis, after hatching and during vitelline resorption showed no mortality or abnormal development of the embryos or the fry from eggs inseminated with frozen sperm. 


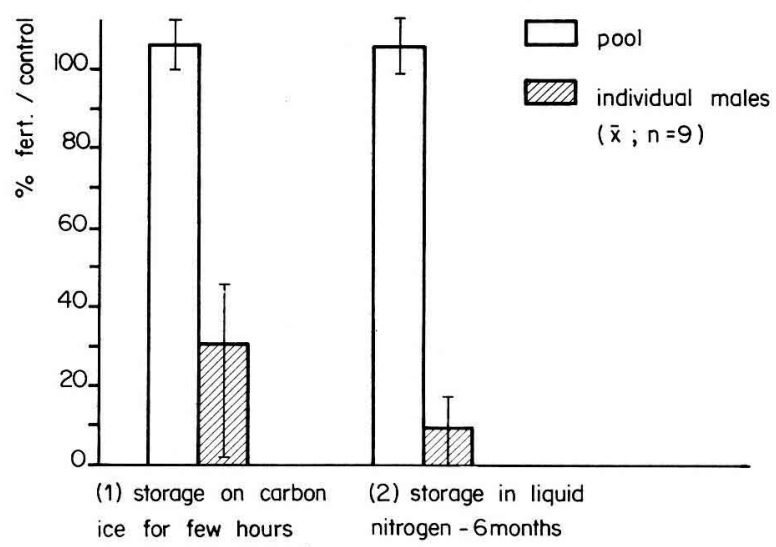

FIG. 4. - Freezing and storage firness of the sperm of 9 males and of their pooled sperm sampled at the end of spermiation. The deviations are the lower (LL) and upper (UL) limits (2 repeats per sperm) ; The fertilization percentages of non-frozen controls were : (1) pooled sperm : 40.7 p. 100 (LL : 38.5 , UL : 42.9 p. 100) ; individual males $(n=9): \bar{x} 49.6$ p. $100(L L: 43.5$, UL : 54.8 p. 100) (2) control sperm (males whose reproduction was advanced by decreasing photoperiod) : $\bar{x} 9.1 \mathrm{p}$. 100 (LL : 8.3 , UL : 10.0 p. 100).

\section{Discussion.}

The results of the present study show that rainbow trout sperm can be cryopreserved for at least several months ; some diluents we used gave satisfactory results and we worked out a freezing-thawing-insemination technique.

Our research has been limited to comparing and improving two diluents used previously with partial success : Mounib's diluent (Mounib, 1978) and Ménézo's B2 diluent (Billard, 1978). Mounib's diluent, including potassium bicarbonate and sucrose, was incontestably better than Ménézo's medium, and the addition of yolk improved it still more. We thus used Mounib's medium, with 10 p. 100 of yolk and 10 p. 100 of DMSO added, in the following conditions : - sperm diluted $1 / 3$, deep-frozen into $100 \mu \mathrm{l}$ peileis, and rapidly thawed (about $10 \mathrm{sec}$ ) in $10 \mathrm{ml}$ of the insemination diluent in the presence of the eggs.

The spermatozoa were undeniably altered, and thus the number of cryopreserved ones to be used for artificial insemination had to be augmented to equal the fertilization percentage obtained with fresh sperm. It is difficult to assess the percentage of surviving sperm (which was approximately $1 / 3$ in Mounib's experiment). Probably more than 50 p. 100 survived but the rate of motility was strongly reduced. The fertile spermatozoa however gave a normal embryonic and post-embryonic development. Sperm fitness for deep-freezing varied slightly from male to male and the pooled sperm of several males gave a better fertilization rate than the mean of the individual values.

Some of these points need discussion.

Development of a freezing diluent.

Adding yolk and, to a lesser degree, BSA, to Mounib's medium improved it, showing that potassium bicarbonate and sucrose only partially guaranteed good 
spermatozoa survival. The favorable action of organic components, such as yolk, might be related to a protecting effect on the spermatozoa membranes to which it would reversibly bind (Watson, 1975).

Although Ménézo's medium is more complete, the poorer results obtained with it might be partly due to an insufficient level of potassium initiating spermatozoa motility and causing early exhaustion. In fact, after water or ID is added, trout spermatozoa motility is brief, lasting 30 to $60 \mathrm{sec}$; afterwards, the fertilizing ability is irreversibly lost. It is thus imperative to keep the spermatozoa in the state of immobility, characteristic of pure sperm, up to thawing and insemination.

Potassium bicarbonate $\left(\mathrm{KHCO}_{3}\right)$, as potassium chloride $(\mathrm{KCl})$ (Schlenk and Kahmann, 1937 ; Billard, 1975), inhibits motility in the Mounib's diluent Although Stoss ef al. (1977) observed morphological changes in the spermatozoa in the presence of carbonates, the diluent itself did not seem toxic. Truscott et al. (1968) reported the toxic effect of DMSO on pure sperm, but as Erdahl and Graham (1978), we did not find any toxicity, so that the lower fertilizing ability of cryopreserved sperm was certainly due to the freezing itself and not to and additionnal, deleterious effect of the diluent. This lower ferfilizing ability was perhaps af least partially compensated for by a reduced dilution rate at insemination (1/100 instead of $1 / 1000$ ), the dilution rate limit with fresh sperm being $1 / 1000$ and sometimes $1 / 10000$ with sperm of exceptional quality. The combination of Mounib medium + yolk + DMSO dit not entirely conserve the performance of fresh sperm and must be improved. In that respect, we observed that the favorable effect of yolk faded when its concentration and that of DMSO increased ; however, in our study, the concentration of those components and the dilution of sperm before freezing varied simultaneously so the effect of those parameters could not be disassociated. It would be profitable therefore to determine the optimal ratio of yolk to DMSO for the $1 / 3$ dilution which seemed to be the best.

Variation in the fitness of sperm for deep-freezing

While the fitness of sperm for freezing varied little within the same group of males, it changed during the period of spermiation. In fact, at the beginning of spermiation in December, the fertilization rates recorded with frozen sperm (individually) were about 50 to 60 p. 100, while in mid February the maximum was 28 p. 100.

Decreased motility and freezing fitness have already been reported in the trout (Billard and Breton, 1976) and the sea-bass (Billard ef al., 1977) and were related to sperm senescence. At the end of spermiation, Chemayel (1975) observed an enzyme depletion in the trout. These aging processes could explain the favorable effect of pooling sperm, if the low freezing fitness of the sperm of each of the males results in changes affecting both seminal fluid and spermatozoa.

The « aging » of the spermatozoa and the seminal fluid might be heterogeneous so that some seminal fluids retain a protecting ability which would benefit the less altered spermatozoa or other sperm having a poorer mineral or organic environment to insure their freezing resistance. Such an hypothesis should not be surprising since good results have been obtained after freezing by mixing the sperm of bulls of different genetic strains (Corteel, personal communication). The problem of sperm quality is thus posed, as well as that of criteria for assessing spermatozoa fitness for freezing. 
During the present study, we noticed that spermatozoa concentration was not a valid criterion. On the other hand, motility after freezing gave a general idea of what to expect in the way of fertilizing ability, thus confirming the observation of Truscott ef al. (1968) who noticed that the most motile sperm was invariably the most fertile. To obtain a more exact criterion, it would thus appear that research should be oriented to analyzing the ionic or organic constituents of seminal fluid, such as proteins or enzymes.

\section{Frozen sperm storage time}

In most studies reported in this paper, the length of storage of frozen sperm did not exceed several days except in one experiment in which sperm was kept in liquid nitrogen for 6 months. The low percentage of fertilization obtained were due to the poor quality of eggs produced off season; this does not therefore mean that frozen sperm storage is limited. In other works (Mounib, 1978 ; Stoss et al., 1978), successfull storage during several months or even a year were reported.

Reçu en février 1980

Accepté en juin 1980.

Acknowledgements. - This work was aided by a grant from the "Conseil Superieur de la Pêche ». We wish to thank Mr. Levillain for the care of the breeding fish and Mr. Marie for monitoring the pisciculture recycling system. We also thank Mrs. Alice Daifuku for help with the English manuscript.

Résumé. Des essais de cryoconservation du sperme de truite Arc-en-ciel Salmo gairdneri ont été pratiqués en prenant au départ deux milieux précédemment mis en œuvre : le milieu de Mounib $(M)$ et le milieu Ménézo $B_{2}\left(M_{e}\right)$ et auxquels ont été ajoutés de l'albumine sérique bovine (BSA) et du jaune d'œuf au tellurite (Institut Pasteur). Ces différents dilueurs de congélation (DC) sont additionnés de 10 p. 100 de DMSO et sont mélangés à du sperme avant d'être congelés sur neige carbonique sous forme de pellets $(100 \mu \mathrm{l})$ et stockés dans l'azote liquide pendant des périodes allant de 3 jours à 6 mois. L'intensité de motiliłé et le pouvoir fécondant du sperme sont établis avant ef après cryoconservation. Après dilution du sperme dans le milieu Ménézo on observe une légère mise en mouvement des spermatozoïdes ce qui entraîne vraisemblablement leur épuisement prématuré eł expliquerait le plus faible pouvoir fécondant observé après décongélation. Le milieu de Mounib se révèle supérieur au milieu Ménézo surtout après addition de 10 p. 100 de jaune d'œuf. Les conditions optimales de congélation sont les suivantes : dilution $1 / 3$, pas d'équilibration après dilution, mais mise immédiate en congélation à la vitesse de 10 à $40^{\circ} \mathrm{C} / \mathrm{min}$. La décongélation doit être rapide - en $10 \mathrm{sec}$ - Cependant, les spermatozoïdes subissent des altérations pendant le processus de congélation-décongélation, et il faut employer, lors de l'insémination, davantage de spermatozoïdes congelés pour égaler le taux de fécondation obtenu avec du sperme non congelé. Cependant, les spermatozoïdes fécondants conduisent à une embryogenèse normale et aucune anomalie de développement n'a été relevée jusqu'au stage résorption de la vésicule. A la fin de la période de spermiation, l'aptitude du sperme à être congelé diminue, ce qui peut être dû à des phénomènes de vieillissement du sperme. La mise en pool du sperme de plusieurs mâles compense au moins partiellement cette perte de pouvoir fécondant observée en fin de période de reproduction. 


\section{References}

BILLARD R., 1975. L'insémination artificielle de la Truite (Salmo gairdneri Richardson). IV. Effets des ions $\mathrm{K}^{+}$et $\mathrm{N}^{+}$sur la conservation du pouvoir fécondant des gamètes. Bull. fr. Pisc., 256, 88-100.

BILLARD R., 1977. Utilisation d'un système Tris-glycocolle pour tamponner le dilueur d'insémination pour truite. Bull. fr. Pisc., 264, 102-112.

BILLARD R., 1978. Some data on gametes preservation and artificial insemination in teleost fish. Actes Coll. CNEXO, 8, 59-73.

BILLARD R., 1980. Survie des gamètes de truite Arc-en-ciel après dilution dans des solutions salines ou de sucrose. Reprod. Nutr. Develop., 20, 1899-1905.

BILLARD R., BRETON B., 1976. Sur quelques problèmes de physiologie du sperme chez les poissons téléostéens. Rev. Trav. Inst. Pêches marit., 40, 501-503.

BILLARD R., DUPONT J., BARNABE G., 1977. Diminution de la motilité et de la durée de conservation du sperme de Dicentrarchus labrax L. (poisson téléostéen) pendant la période de spermiation. Aquaculfure, 11, 363-367.

BILLARD R., JALABERT B., 1974. L'insémination artificielle de la truite (Salmo gairdneri Richardson). II. Comparaison des effets de différents dilueurs sur la conservation de la fertilité des gamètes avant et après insémination. Ann. Biol. anim. Bioch. Biophys., 14, 601-610.

CHEMAYEL M., 1975. Efude de la variabilité du pouvoir fécondant du sperme en relafion avec ses caractéristiques chez la truite Arc-en-ciel (Salmo gairdneri). Th. Doct. 3e Cycle, Univ. Paris VI.

ERDAHL D. A., GRAHAM E. F., 1978. Cryopreservation of salmonid spermatozoa. Cryobiology, 15, 362-364.

GRAYBILL J. R., HORTON H. F., 1969. Limited fertilization of steelhead trout eggs with cryopreserved sperm. J. Fish. Res. Bd. Can., 26, 1400-1404.

HOYLE R. J., IDLER D. R., 1968. Preliminary results in the fertilization of eggs with frozen sperm of Atlantic salmon (Salmo salar). J. Fish. Res. Bd. Can., 25, 1295-1297.

MÉNÉZO Y., 1976. Milieu synthétique pour la survie et la maturation des gamètes et pour la culture de l'œuuf fécondé. C. R. Acad. Sci. Paris, sér. D, 282, 1967-1970.

MOUNIB M. S., 1978. Cryogenic preservation of fish and mammalian spermatozoa. J. Reprod. Fert., 53, $13-18$.

NAGASE H., 1964. Deep freezing bull semen in concentrated pellet form. I. Factors affecting survival of spermatozoo. Proc. int. Congr. Reprod. anim. Insem. Artif., Trento, 4, 410-415.

OTT A. G., HORTON H. F., 1971a. Fertilization of chinook and coho salmon eggs with cryopreserved sperm. J. Fish. Res. Bd. Can., 28, 745-748.

OTT A. G., HORTON H. F., 1971b. Fertilization of steelhead trout (Salmo gairdneri) eggs with cryopreserved sperm. J. Fish. Res. Bd. Can., 28, 1915-1918.

SANCHEZ-RODRIGUEZ M., BILLARD R., 1977. Conservation de la motilité et du pouvoir fécondant du sperme de la truite Arc-en-ciel maintenue à des températures voisines de $0^{\circ} \mathrm{C}$. Bull. fr. pisc., 265, 144-152.

SCHLENK W., KAHMANN H., 1937. Die chemische Zusammensetzung des Spermaliquors und ihre physiologische Bedeutung. Untersuchung am Forellensperma. Biochem. Z., 295, 283-301.

STEIN H., BAYRLE H., 1978. Cryopreservation of the sperm of some freshwater teleosts. Ann. Biol. anim. Bioch. Biophys., 18, 1073-1076.

STOSS J., BÜYÜKHATIPOGLU S., HOLTZ W., 1977. Ber einflub bestimmter elektrolyte auf die Bewegungsanslösung bei spermatozoen der Regenbogenforelle (Salmo gairdneri). Zuchthygiene 12, 178-184.

STOSS J., BÜYÜKHATIPOGLU S., HOLTZ W., 1978. Short-term and cryopreservation of rainbow trout (Salmo gairdneri Richardson) sperm. Ann. Biol. anim. Bioch. Biophys., 18, 1077-1082.

TRUSCOTT B., IDLER D. R., 1969. An improved extender for freezing atlantic salmon spermatozoa. J. Fish. Res. Bd. Can., 26, 3254-3258.

TRUSCOTT B., IDLER D. R., HOYLE R. J., FREEMAN H. C., 1968. Sub-zero preservation of atlantic salmon sperm. J. Fish. Res. Bd. Can., 25, 363-372.

WATSON P. F., 1975. The interaction of egg yolk and ram spermatozoa studied with a fluorescent probe. J. Reprod. Fert., 42, 105-111. 